\title{
Pós-ModernisMo: ENTRE A Crítica e a IDEOLOGIA ${ }^{1}$
}

Gustavo Moura de Cavalcanti Mello

RESUMO: O objeto deste artigo é a noção de pós-modernismo, em torno da qual se travou um amplo debate que, num passado recente, alcançou grande projeçáo, e arrefeceu de modo algo abrupto. Buscaremos demonstrar que uma consideraçáo crítica acerca do referido debate amplia nossa compreensão a propósito do capitalismo contemporâneo e, nesse sentido, por um lado, será realizado um esforço de apreensão conceitual, com o intuito de fixar as principais determinaçóes (e indeterminaçóes) do pós-modernismo. Por outro lado, tentaremos ancorar historicamente o debate sobre o pós-modernismo, localizando certas articulaçóes entre o desenvolvimento teórico e o processo histórico que lhe é subjacente.

PALAVRAS-CHAVE: Pós-modernidade. Pós-modernismo. Ideologia. Marxismo. Capitalismo contemporâneo.

\section{INTRODUÇão}

Parece salutar que principiemos a aproximação ao tema precisando, em linhas gerais, ao que se referem os termos "pós-modernismo" ou "pósmodernidade": a um movimento estético? A uma estrutura epistemológica ou cognitiva? A uma nova era que teria sido aberta à humanidade? A uma determinada fase de desenvolvimento do capitalismo? Entretanto, reside justamente aí um conjunto de obstáculos. De saída, percebe-se que os próprios termos, pela falta de autorreferenciação, indicam uma etapa de transição, algo indefinida e instável. Por outro lado, o prefixo "pós" denota uma ruptura, seja no tempo, seja na dimensão das formas e dos conteúdos. O desafio logo se agiganta, se se considera, junto com Perry Anderson, que a história das vicissitudes do moderno e de suas múltiplas relaçôes com o pós-moderno “[...]

\footnotetext{
${ }^{1}$ http://dx.doi.org/10.1590/S0101-317320160001000011

${ }^{2}$ Graduado em Economia pela Faculdade de Economia e de Administraçẫo da USP (2004); Mestre (2007) e Doutor (2012) em Sociologia pela Faculdade de Filosofia, Letras e Ciências Humanas da USP. Pós-doutorando e professor colaborador junto ao Departamento de Sociologia do IFCH-Unicamp. E-mail: gusmcmello@usp.br.
} 
ainda é recente demais para uma interpretação desapaixonada que faça justiça a todas as suas contradiçóes." (ANDERSON, 1999, p.119).

Ora, caso nos fixemos, por exemplo, em fenômenos estéticos e epistemológicos por vezes reunidos sob a noção de pós-modernismo (em oposição à de pós-modernidade, que designaria uma época histórica), notamos que, enquanto a teorização e a subsunção de toda uma gama de vertentes artísticas e teóricas ao conceito de moderno se deram de maneira post festum, a mobilização generalizada da noção de pós-moderno não foi nada tardia; na realidade, converteu-se num rótulo que aderia a boa parte das obras estéticas e teóricas após a difusão e consagração do termo, na década de 1970. Por outro lado, enquanto o modernismo estético se caracteriza pelos manifestos, pelas marcadas diferenciaçóes reivindicadas por parte de coletivos coesos e conscientemente inovadores, com base em sólidos princípios políticos e estéticos, o pós-modernismo caracteriza-se sobremaneira pela indiferenciação, pela experimentação descompromissada, numa pretensa fuga ao formalismo e ao doutrinário ${ }^{3}$. Não foi por acaso que, por vezes, a conceituação de pósmodernismo se confundiu com a mera listagem caótica e heterogênea de autores, obras, e gêneros ${ }^{4}$.

Se nos voltássemos, ao contrário, para as acepçóes pós-modernas relativas às formas contemporâneas de sociabilidade, ao atual padrão de desenvolvimento tecnológico, às formas dominantes de produção e consumo, e assim por diante, as dificuldades não seriam menores; também aqui prevaleceria a dispersão, o ecletismo e a apologética falastrona, em detrimento da crítica. Tentemos, então, encontrar um solo mais firme para essa investigação.

\section{A Consagração do Pós-Modernismo}

Dados os limites deste artigo, não caberia fazer uma genealogia do termo (ANDERSON, 1999, p.9-21); partamos da generalização de seu uso, na década de 1970. Um marco nesse processo foi a publicação do periódico Boundary 2 - Revista de Literatura e Cultura Pós-Modernas, na qual o pós-modernismo foi apresentado pela primeira vez como referência coletiva (ANDERSON,

\footnotetext{
3 "O universo pós-moderno não é de delimitação, mas de mistura, de celebração do cruzamento, do híbrido, do pot-pourr." (ANDERSON, 1999, p.110).

4 "Se o pós-modernismo cobre tudo desde o punk à morte da metanarrativa, dos fanzines a Foucault, como conceber que um único esquema explanatório possa fazer justiça a uma entidade de uma heterogeneidade tão fantástica assim?” (EAGLETON, 1998, p.30).
} 
1999, p.23). Um destacado colaborador da revista, Ihab Hassan, em busca de elementos de radicalização ou de negação do modernismo, teve o mérito de estender suas análises sobre o pós-modernismo a diversos campos da produção estética, como as artes visuais e a música, e além deles, incluindo a tecnologia e, posteriormente, a ciência e a filosofia. Com forte veia antimarxista, Hassan pretendia se esquivar à política, a qual encarava com desconfiança, ao mesmo tempo em que decretava a obsolescência das distinçóes entre esquerda e direita do campo político, materialismo e idealismo, base e superestrutura (ANDERSON, 1999, p.26-27).

Apesar de aglutinar sob a noção de pós-modernismo um espectro bastante amplo e heterogêneo de manifestaçóes culturais, indo do conceitualismo a Andy Warhol, a preferência de Hassan recaía sobre as produçóes que tinham por referência "[...] as formas exasperadas do modernismo clássico". Desse modo, bastante decepcionado, em meados da década de 1980, Hassan se viu compelido a avaliar os rumos do pós-modernismo, concluindo que

[...] o próprio pós-moderno mudou, dando, a meu ver, a guinada errada. Encurralado entre a truculência ideológica e a ineficácia desmistificadora, preso no seu próprio kitsch, o pós-modernismo tornou-se uma espécie de pilhéria eclética, refinada lascívia de nossos prazeres roubados e descrenças fúteis (HASSAN apud ANDERSON, 1999, p.28).

Foi justamente esse pós-modernismo que se generalizou, tendo como principal vetor correntes da arquitetura afirmadas em Learning from Las Vegas (1972), de Robert Venturi, Denise Scott Brown e Steven Izenour. Nesse pequeno, porém contundente texto, pululam invectivas contra a arquitetura moderna ortodoxa, em favor de um conformismo cínico ante os imperativos do mercado. Lê-se, por exemplo, que

[...] a faixa comercial [...] desafia o arquiteto a adotar uma visão positiva, náo ressentida. Arquitetos estão desacostumados a olhar o ambiente sem julgamentos, porque a arquitetura moderna ortodoxa é progressista, se não revolucionária, utópica e purista: mostra-se insatisfeita com as condiçóes existentes [...]. Os arquitetos têm preferido mudar o ambiente existente, ao invés de melhorar o que está aí. (VENTURI; BROWN; IZENOUR; 1995, p.5).

Em oposição a essa arquitetura, frisam os autores: “[...] os valores de Las Vegas não são questionados aqui. A moralidade da propaganda comercial, 
os ganhos do jogo e o instinto competitivo não estão em questão aqui." (VENTURI; BROWN; IZENOUR, 1995, p.6).

Aproveitando o filáo aberto por seu professor Robert Venturi, Charles Jencks adquiriu projeção internacional, num momento em que o pósmodernismo já se tornara dominante na arquitetura, e só viria a vicejar. De acordo com Anderson (1999, p. 31), “[...] em meados da década de 1980, Jencks festejava o pós-moderno como uma civilização mundial de tolerância pluralística e opçóes superabundantes, uma civilização que 'tornava sem sentido' polaridades ultrapassadas como 'esquerda e direita, capitalista e classe operária”" e decretava o fim das vanguardas e das ideologias, já que “[...] não há inimigo para derrotar". $\mathrm{O}$ pós-modernismo anunciava a produção de uma "[...] ordem simbólica comum do tipo fornecido por uma religião." (ANDERSON, 1999, p.32).

Também determinante para a projeção internacional do pósmodernismo foi a teorização desenvolvida por François Lyotard. A publicação de $A$ Condição Pós-moderna, em 1979, teve ampla repercussão, e sua obra logo se tornou uma referência obrigatória do debate em torno do pós-modernismo e da pós-modernidade, desse momento em diante relacionados a mudanças decisivas na própria "condição humana”. Segundo Lyotard, a pós-modernidade, fruto do advento da sociedade pós-industrial (LYOTARD, [1979] 2004, p.5), definia uma sociedade constituída como um grande conjunto de jogos de linguagem, diversos e incomensuráveis entre si. Em suas palavras, o termo pós-moderno “[...] designa o estado da cultura após as transformaçóes que afetaram as regras dos jogos da ciência, da literatura e das artes a partir do final do século XIX. Aqui, essas transformaçóes serão situadas em relação à crise dos relatos" (LYOTARD, 2004, p. XV), que legitimariam os metadiscursos característicos da ciência moderna (LYOTARD, 2004, p. XVI, p.69).

Assim, a ciência e a filosofia, objeto principal de Lyotard na obra em questão, seriam portanto apenas alguns dentre tantos "jogos de linguagem”, sem gozar de qualquer primazia. A "aura" que as recobriu outrora emanaria de duas grandes narrativas justificadoras da modernidade, relacionadas ao iluminismo francês e ao idealismo alemão - aos quais, numa obra posterior, Lyotard acrescenta a "narrativa marxista" -, "narrativas" estas invariavelmente enredadas na escatologia cristã e na promessa do retorno "ao significante pleno" (o "Pai único, justo e bom”), como "fim último" (LYOTARD, [1993] 1996, p. 93-4). Em função do próprio desenvolvimento interno das ciências, relativo à "pluralização do argumento" e à "tecnificação da prova" ("na qual aparatos 
dispendiosos comandados pelo capital e pelo Estado reduzem a 'verdade' ao desempenho"), na pós-modernidade essas narrativas-mestras teriam se esfacelado. Com isso, transformou-se o estatuto dos saberes (LYOTARD, 2004, p.71-2), com a prevalência do saber-mercadoria (LYOTARD, 2004, p.5) e a tecnificação e a automatização da reprodução social, sob a égide de especialistas e gestores de distintos matizes (LYOTARD, 2004, p.27). No bojo desse processo, Lyotard saúda a tendência à extensão do "contrato temporário" ao conjunto das dimensóes da vida social (empregatícia, evidentemente, mas também amorosa, sexual, política etc.), que levaria ao seu enriquecimento, quando comparado à rigidez moderna.

Diga-se de passagem, apesar de não formulá-lo explicitamente, subjacente ao elogio de Lyotard ao advento da pós-modernidade se encontra uma interpretação algo linear da modernidade e das ditas metanarrativas que lhe seriam características como um caminho que conduz invariavelmente ao totalitarismo, de direita ou de esquerda (EAGLETON, 1987).

Malgrado seu sucesso, como enfatiza Anderson, A Condição Pós-moderna não era a mais exaustiva e fiel expressão do pensamento de seu autor ${ }^{5}$. Ao invés do "estado geral do conhecimento" de sua época, os principais interesses de Lyotard eram as artes e a política, esta última sempre presente como objeto de reflexáo, ao longo de sua trajetória. Oriundo de uma esquerda heterodoxa e radical, Lyotard militou entre 1954 e 1964 no grupo Socialisme ou Barbarie e, posteriormente, foi membro do Pouvoir Ouvrier, por mais dois anos. A essa altura, impactado pela integração operária à Quinta República, Lyotard deixou de ver o proletariado como força revolucionária (LYOTARD, 1996, p.73), e não tardou a se envolver com o levante estudantil de 1968, na França.

De acordo com essa nova ótica, a classe operária fora substituída pela "juventude" como agente subversivo, e o fomento de estratégias e táticas revolucionárias proletárias fora suplantado pela defesa de condutas votadas à intensificação libidinal e afetiva. Como avalia Anderson (1999), a imagem do capital como um moto perpétuo de desejos, refletida a partir do refluxo da esquerda e do ascenso do consumismo, também ofuscou a Lyotard, que levou o argumento ao limite: a dinâmica da acumulação capitalista deveria ser traduzida em termos de uma economia libidinal; a própria experiência da labuta

\footnotetext{
${ }^{5}$ Ao contrário, em suas próprias palavras, nesse livro, feito por encomenda do governo de Quebec, "[...] construí histórias, me referi a uma quantidade de livros que nunca li. Parece que isso impressionou as pessoas, é tudo um pouco paródia [...] É simplesmente o pior dos meus livros, que são quase todos ruins; mas este é o pior" (LYOTARD apud ANDERSON, 1999, p.56).
} 
sob condiçôes insalubres, levada à exaustão física, à mutilação, à degradação dos sentidos e ao massacre de geraçóes de trabalhadores, no seio da Primeira Revolução Industrial, por exemplo, era por estes desejada, propiciando-lhes masoquista ou histericamente - consideráveis doses de prazer (!).

Por conseguinte, em seu combate ao reformismo, aparentemente este levou a melhor e passou a impregnar a crítica de Lyotard. A própria perspectiva de emancipação teria sido abarcada e internalizada pelo capital, que se alimentaria das dissonâncias e dos desafios impostos por setores da sociedade organizados em torno de suas bandeiras particulares. Em suas palavras,

[...] a emancipação já não se situa como alternativa à realidade, como um ideal a conquistar contra ela e a impor-lhe de fora. É, antes, um dos objetivos que o sistema tenta atingir em um ou outro dos setores do qual é composto, trabalho, imposto, mercado, família, sexo, 'raça', escola, cultura, comunicação. Não é em toda parte que ele é bem-sucedido, ele se depara com resistências, internas e externas. Mas os próprios obstáculos que lhe são opostos obrigam o sistema a se tornar mais complexo e a se abrir mais, a promover novos empreendimentos. A emancipação faz-se tangível. (LYOTARD, 1996, p. 69).

Acompanhando essa evolução teórica, outras dimensôes da análise de Lyotard sobre o sistema capitalista sofreram mutaçóes, até culminar em formulações igualmente surpreendentes. Em evidente contraposição àquilo que ele apresentava como a metanarrativa marxista, uma profecia da emancipação da humanidade pelas mãos do proletariado, Lyotard acabou por situar o capitalismo numa longa trama, determinada em última instância pela entropia e pela "neguentropia": em meio a toda sorte de contingência e interaçôes energéticas, um planeta foi berço de formas de vida que passaram a disputar entre si pelo acesso à energia limitada (LYOTARD, 1996, p. 8384), coagidos pelo "[...] princípio da seleção mecânica dos sistemas mais bem 'adaptados" (LYOTARD, 1996, p .85). Do jogo evolutivo que assim se produziu surge a espécie humana, que logrou estabelecer um sem-número de formas de agregaçáo, em torno da tarefa de "[...] descobrir, captar e conservar fontes de energia", numa trajetória que teve como "[...] grandes eventos" a revolução neolítica e a revolução industrial (LYOTARD, 1996, p. 86). O capitalismo e as democracias liberais aparecem então como a forma mais eficiente de cumprir com essa "sina", em detrimento dos "mundos" comunista e islâmico (LYOTARD, 1996, p. 87). Diante de tamanho triunfo, a única ameaça e o único limite ao desenvolvimento capitalista seria a própria extinção 
do sol, para o que toda a pesquisa contemporânea buscaria uma resposta, conscientemente ou náo.

O capitalismo se torna assim um pequeno episódio numa história de bilhóes de anos, como fruto de uma espécie de seleção natural atuante, desde os primórdios da galáxia. Ao filósofo talvez fosse reconfortante fazer-se o anunciador dessa epopeia universal, expondo em largos traços a "astúcia da razão energética" que rege nosso destino. Entretanto, evidencia-se que, ao ter como alvo as "metanarrativas" modernas, particularmente a "marxista", Lyotard acaba por apelar a uma grandiosa metanarrativa, que seria pósmoderna por ser, ao mesmo tempo, "física" e "diacrônica", e sobretudo por não ser tributária da noção de emancipação (LYOTARD, 1996, p. 97). Ora, por um lado, o horizonte da emancipação não havia sido apresentado por ele como determinação necessária às grandes narrativas modernas; por outro, o que seria o êxodo do planeta, e a fuga ao trágico destino ditado pela lei da entropia, senão uma promessa de salvação e de emancipação? Uma promessa, aliás, um tanto ambiciosa, que projeta a emancipação num horizonte espaçotemporal cósmico ("o cosmos é o limite!"). Uma das principais diferenças entre o espantalho que Lyotard aponta como a "grande narrativa marxista" e a narrativa que ele próprio apresenta é que agora a emancipação seria um resultado automático do referido conflito entre entropia e neguentropia (ANDERSON, 1999, p. 41-42). Parece antes uma versão caricatural da teleologia idealista.

Do lado das artes, Lyotard veio a apresentar o pós-modernismo como um movimento de renovação do modernismo, interno e inerente a ele. Tratava-se de uma polêmica contra posiçôes similares à de Charles Jencks e contra a estética arquitetônica que se tornava hegemônica, a qual, em sua acepção, não passava de um requentar do realismo outrora mobilizado pelos regimes totalitários alemão e soviético, plasmado em ecletismo cínico, sob auspícios do grande capital. Ao contrário, Lyotard prezava as correntes que preservaram o ímpeto e a força das vanguardas, dando destaque ao minimalismo. Existe uma assimetria entre a abordagem estética de Lyotard e suas teses sobre o conhecimento pós-moderno; enquanto este último é tido como um estágio definido no tempo, fruto de uma longa evolução histórica, a primeira é apresentada como um princípio perene, e Lyotard parece nutrir a esperança de uma vivificação do alto modernismo (ANDERSON, 1999, p. 38; JAMESON, 2007, p. 84). 
Outra intervenção de destaque no debate sobre o pós-modernismo e a pós-modernidade, importante para sua consagração, foi a de Jürgen Habermas, principalmente em seu discurso "Modernidade - Um projeto incompleto" (1981), e na conferência "Arquitetura Moderna e Pós-Moderna" (1987). A repercussão dessas preleçóes decorreu tanto do sucesso de que gozava Habermas, à época, quanto de sua posição crítica ao pós-modernismo, o qual, segundo ele, estaria fortalecendo uma postura neoconservadora antimodernista, cada vez mais difundida.

Para compreender o lugar assumido por Habermas, nesse debate, talvez seja necessário remeter a algumas de suas teses fundamentais, já que sua análise do pós-modernismo parece uma "aplicação" do arcabouço analítico que ele vinha desenvolvendo. É arquiconhecida a diferenciação habermasiana entre dois tipos de racionalidade ou de ação racional, a teleológica e a comunicativa ${ }^{6}$, com base nas quais ele distingue analiticamente entre "[...] o enquadramento institucional de uma sociedade ou de um mundo vital sociocultural, e os subsistemas da ação racional relativa a fins que se 'incrustam' nesse enquadramento" (HABERMAS, 1968, p. 60), separando assim o "mundo da vida", definido pelas "[...] tradiçóes culturais, ordens legítimas e indivíduos socializados" (HABERMAS, 1987, p. 258), e o "sistema”.

Apesar de seu projeto de fazer a Teoria Crítica "[...] passar do paradigma da ação teleológica ao da ação comunicativa” (HABERMAS, 1987a, p. 433), a totalidade social redundaria da interação dinâmica e complexa entre ambos universos, e seu bom funcionamento, bem como a efetivação de seus potenciais de emancipação, exigiriam que se preservasse, como instâncias autônomas, os subsistemas nos quais vigora a ação teleológica. Segundo Habermas (1991, p. 56), “[...] as mudanças revolucionárias que se efetuam sob nossos olhos contêm um ensinamento inequívoco: sociedades complexas não podem se reproduzir se não deixam intacta a lógica da auto-orientaçáo de uma economia regulada pelos mercados". Coerentemente com a tese de que não se pode almejar uma alteração substantiva no âmbito do "sistema", sob o risco da regressão social, e contra as proposições de Marcuse (1969), Habermas crê existir uma "conexão imanente" entre a técnica e a racionalidade teleológica, donde a impossibilidade de uma transformação na essência da técnica (HABERMAS, 1968, p. 52-53).

\footnotetext{
6 "Por 'trabalho' ou açâo racional teleológica entendo ou a ação instrumental ou a escolha racional ou, entấo, uma combinaçẫo das duas [...]. Por outro lado, entendo por ação comunicativa uma interação simbolicamente mediada. Ela orienta-se segundo normas de vigência obrigatória que definem as expectativas recíprocas de comportamento e que têm de ser entendidas e reconhecidas, pelo menos, por dois sujeitos agentes." (HABERMAS, 1968, p. 57-58).
} 
Em meio à apresentação desse modelo abrangente e um tanto harmonioso, Habermas é capaz de construir uma teoria democrática alternativa ao liberalismo (HABERMAS, 1987a, p.452). Desse modo, ele propugna que, com o advento da sociedade burguesa, entre o Estado e a sociedade civil teria sido criada a esfera pública, na qual ocorre o "[...] uso público da razão estabelecendo um princípio de igualdade entre os indivíduos", que estabelece e se pauta pela "[...] autoridade do melhor argumento" ou pela "coação não coercitiva do melhor argumento" (HABERMAS, 1987a, p.466, 2000, p.186,).

Sem dúvida, Habermas parecebastanteimpactado pelo intervencionismo estatal na economia e pela importância adquirida pelo Welfare State, nos países capitalistas centrais, que o levam a concluir que "[...] a política já não é apenas um fenômeno superestrutural”, mas se torna imprescindível para a própria dinâmica da valorizaçấo do capital, de maneira que "[...] o marco institucional da sociedade repolitizou-se” (HABERMAS, 1968, p. 69). Entretanto, por um lado, com essa instrumentalização do Estado, que tem por finalidade última a garantia do "bom funcionamento" da economia, e que leva Habermas (1968, p. 70) a concluir que a "[...] política visa não à realização de fins práticos, mas a resolução de questóes técnicas”, e, por outro, com a colocaçáo do desenvolvimento técnico-científico em primeiro plano, tendo a técnica e a ciência se tornado, supostamente, a principal força produtiva, cria-se uma ideologia que apregoa a total dependência da organização social em relação ao progresso técnico-científico (HABERMAS, 1968, p.72). Segundo Habermas (1968, p. 84), "[...] o limiar da modernidade caracterizar-se-ia, entấo, por esse processo de racionalização que se iniciou com a perda da 'intocabilidade' do marco institucional pelos subsistemas da ação racional dirigida a fins". Desse modo, a modernidade seria marcada tanto pela criação de novos espaços sociais organizados comunicativamente, quanto pela sua "colonizaçáo" pelas formas de ação características dos subsistemas em que vige a ação regida por fins (HABERMAS, 1987b, p. 244, 259).

No que tange à discussão sobre o pós-modernismo propriamente dita, de maneira talvez excessivamente sintética, com base em Habermas (1981), poder-se-ia apresentar a posição de Habermas da seguinte forma: a separação entre arte, ciência e moral, cada qual com sua norma específica (beleza, verdade e justiça) e perfazendo esferas autônomas de valor, processo esse característico e inerente à modernidade, libertou enormes potências criativas e de emancipação. No entanto, ao invés de propiciar o enriquecimento da experiência cotidiana, o que se deu foi uma superespecialização que fechou 
tais esferas à compreensão comum. Não obstante, se com isso o modernismo havia perdido sua vitalidade, a derrota não estaria consumada. Haveria de se estabelecer uma nova interação entre as esferas de valor autônomas e o mundo da vida, derrubando as barreiras criadas à apropriação da cultura pelo conjunto da sociedade. Para tanto, far-se-ia necessário criar óbices à colonização do mundo da vida pelo mercado e pela administração burocrática. Em resumo, diante do ascenso do pós-modernismo, a questão-chave que Habermas (1981, p. 9). se coloca é: "[...] devemos sustentar as intençóes do Esclarecimento, débeis como possam estar, ou devemos declarar todo o projeto da modernidade uma causa perdida?” Dessa encruzilhada é que Habermas desponta, uma vez mais, como defensor do Esclarecimento.

Sob essa perspectiva, longe de contribuir com essa decisiva tarefa, diversas correntes do pós-modernismo, idealizadoras de um passado perdido no qual a dinâmica social menos complexa teria propiciado formas de interaçáo humana mais orgânicas e desejáveis, cumpririam função oposta. De acordo com Habermas (1987, p. 124).

[...] a nostalgia de formas de vida menos diferenciadas às vezes confere a estas tendências a tintura do antimodernismo. Nestes casos elas se combinam ao culto da tradição local e à veneração da banalidade. Esta ideologia da infracomplexidade renega o potencial racional e o sentido específico da modernidade cultural.

Enfim, no que tange especificamente à abordagem de Habermas sobre o tema da arquitetura moderna e pós-moderna, parece-nos precisa a crítica de Otília Arantes, segundo a qual

[...] não é possível dissociar a evolução de conjunto da arte moderna [...] de sua forma de inserção no mundo da produção capitalista, diluindo suas aporias na abstraçáo dos 'equívocos categoriais', das 'sobrecargas indevidas', dos 'programas extravagantes' etc. À medida que a formamercadoria se generaliza, e no caso da arte de massa, que é sobretudo o caso da arquitetura contemporânea, se estende até a forma-publicidade, a sujeição da funcionalidade estrita à funcionalidade sistêmica, além de fatal, é o primeiro dado do problema e, de modo algum, um acréscimo extrínseco. (ARANTES, 2001, p. 62-63).

Seria um equívoco concluir, dessa mirada geral, que as trajetórias do modernismo e do pós-modernismo são lineares, sem nuances e contradiçôes, 
desconsiderando as tensôes e o potencial crítico e subversivo que tiveram algumas de suas manifestaçóes, em certas conjunturas. Mas não há dúvida de que esse registro fundamental da análise - numa palavra, as imbricaçóes entre a forma-mercadoria ou a forma-capital e a forma estética -, escapa complemente a Habermas. De fato, como assevera Löwy (2000, p. 220), “[...] poderíamos resumir o projeto político-cultural de Habermas como uma tentativa de tornar a sociedade burguesa mais fiel à sua própria utopia racionalista”.

Fosse o caso de criticar mais detidamente as teses de Habermas, haveria de se considerar, em primeiro lugar, como esse autor conscientemente substitui "[...] a duplicidade dialética valor/valor de uso pela dualidade estrutural sistema/mundo da vida" (PRADO, 2005, p. 20), abstraindo de seus objetos a forma social que os reveste e plasma, o próprio conceito de capital 7 . Por outro lado, e com esse pano de fundo, seria necessário criticar sua concepção idealista sobre a "comunicaçáo" e a "linguagem", por exemplo, recordando as considerações de Adorno e Horkheimer (1985, p. 49) sobre o sistema administrativo "[...] que preforma todos os setores da vida moderna, inclusive a linguagem e a percepção", e que dispóe como seus principais "instrumentos da dominação", "[...] a linguagem, as armas e por fim as máquinas" (ADORNO; HORKHEIMER, 1985, p. 48; HORKHEIMER, 2002, p. 30-1; ADORNO; HORKHEIMER, 1985, p. 31-33, 83, 138). Porém, uma crítica mais detida do pensamento de Habermas foge ao escopo deste artigo.

Diga-se de passagem, como enfatiza Anderson (1999), tanto Lyotard quanto Habermas abordaram o tema da pós-modernidade de modo pouco rigoroso, sem fornecer uma "[...] interpretação histórica [...] capaz de definilo no tempo ou no espaço"; ao contrário, deram-lhe, por um lado, um "tratamento filosófico superficial sem conteúdo estético significativo", e por outro, uma "[...] percepção estética sem um horizonte teórico coerente" (ANDERSON, 1999, p. 53).

\footnotetext{
${ }^{7}$ Como constata Prado (2005, p. 33), “[...] na reconstrução habermasiana o conceito de capital como valor que se valoriza, como sujeito automático, como substância que é sujeito, desaparece de maneira sub-reptícia. Se isto, por um lado, lhe permite valorizar positivamente o sistema econômico como um processo homeostático que desonera o mundo da vida das tarefas que ele não pode realizar, por outro, isto o leva a subestimar o potencial destrutivo do modo de produção capitalista”.
} 


\section{Minando os Consensos}

Com forte caráter populista, em oposição ao "espírito de vanguarda" e ao inconformismo característicos do modernismo, o pós-modernismo se difundiu por todo o globo, tornando-se hegemônico como jamais o modernismo esteve perto de ser. Uma importante característica do pósmodernismo seria a destruição das linhas divisórias - tão caras ao modernismo -, entre a "alta cultura" e a "cultura de massa", sob a égide do consumismo desenfreado. Assim, uma série de produçôes estéticas passa a incorporar afirmativamente elementos formais e conteudísticos da indústria cultural, outrora tidos como a antítese da arte (JAMESON, 1998, p. 2).

Numa primeira mirada, o pós-modernismo teria a função de dar cabo às características conservadoras, rígidas e castradoras do moderno. Não obstante, fugindo à mera aparência, vê-se que a

[...] tarefa ideológica fundamental do novo conceito, entretanto, deve continuar a ser a de coordenar as novas formas de prática e de hábitos sociais e mentais [...] e as novas formas de organização e de produção econômica que vêm com a modificação do capitalismo - a nova divisão global do trabalho - nos últimos anos. (JAMESON, 2007, p. 18).

A referida tarefa consiste ainda em revestir o que é familiar com novas roupagens, e dissimular ou estetizar o velho predomínio do econômico, com seu imperativo do lucro. $\mathrm{O}$ sucesso em sua execução denota a amplitude e a profundidade do pós-moderno como dominante cultural contemporânea, penetrando de assalto o plano do vivido de importantes contingentes populacionais. $\mathrm{O}$ que, cabe ressaltar, nada diz sobre a coerência e o rigor das produçôes teóricas e estéticas pós-modernas, mas sim sobre sua pertença à totalidade social (ANDERSON, 1999, p. 132).

Há de se ter presente, portanto, certa aderência imediata - apesar de mistificadora - de manifestaçôes pós-modernas ao plano fenomênico. Criticando os filósofos pós-modernos desconstrutivistas, constata Schwarz (1999, p. 158-159) que

[...] a realidade começava a se parecer com a filosofia, no caso, com a terra movediça postulada pelo desconstrucionismo [...]. Nessas circunstâncias, a desestabilizaçáo dos sujeitos, das identidades, dos significados, das teologias - especialidades enfim do exercício de leitura pós-estruturalista - adquiriu uma dura vigência prática. [...] [Com isso] a desconstrução filosófica, 
apesar do esoterismo, chega a parecer uma descrição vulgarmente empírica de notórios equívocos e desenganos contemporâneos ${ }^{8}$.

Ainda sobre a dimensão ideológica do pós-modernismo, também chama a atenção uma espécie de bifurcação. Quando se engajam em debates sobre a cultura, os "pós-modernos" comumente se ancoram à categoria de diferença, afirmando a pluralidade e a alteridade, geradoras de sinergias e interaçóes criativas etc. (JAMESON, 2007, p.57); ao passo que, ao frisarem o econômico, apelam à categoria de identidade, a quebra das barreiras e dos localismos, a integração dos mercados, a livre iniciativa e a igualdade de condiçóes nos espaços competitivos internacionais etc. Desse modo, somos mantidos longe da categoria de contradição, a qual, na acepção marxiana, redundaria da interação dialética entre identidade, diferença, e oposição, todas elas ideológicas quando tomadas isoladamente. Por esse motivo, Fausto (1987, p. 319) salienta que "[...] no capitalismo contemporâneo náo é mais a identidade mas a diferença que oculta a contradição [...]. A diferença [...] revela a contradição, no sentido, negativo, de que questiona a identidade, mas ao mesmo tempo a mistifica”.

À falta de abordagens concorrentes, no final da década de 1970, os temas do pós-modernismo e da pós-modernidade eram "apanágio da direita”. Foi principalmente por meio do esforço de Frederic Jameson que a noção de pós-modernidade foi arrancada do campo conservador e apologético do qual era mantida cativa.

Pelas mãos de Jameson, a pós-modernidade se tornava a expressão cultural de uma nova etapa do desenvolvimento do capitalismo, ou a "[...] dominante cultural da lógica do capitalismo tardio” (JAMESON, 2007, p. 72), e não simplesmente um desdobramento ou ruptura estética e epistemológica. Em suas palavras, a pós-modernidade deveria ser apreendida como "[...] um conceito de periodização cuja função é correlacionar a emergência de novas determinaçôes formais na cultura com a emergência de um novo tipo de vida

\footnotetext{
${ }^{8}$ Diga-se de passagem que, em diversos escritos pioneiros, Schwarz desenvolveu uma poderosa crítica às produçôes pós-modernas em ascensão. Poder-se-ia nesse sentido destacar a crítica ao Tropicalismo (incluindo o Cinema Novo) e ao Teatro de Arena, presente em "Nota sobre vanguarda e conformismo" e em "Cultura e Política, 1964-9: alguns esquemas", ambos compilados em (SCHWARZ, 2008), no interior das quais Schwarz analisa a "[...] anulaçăo entre vanguarda e o popular, entre a cultura 'séria' e de consumo"; critica a estética do "disparate" e seu ímpeto "nostálgico" e "melancólico", bem como "o valor absoluto do novo", entre vários outros temas e aspectos do pós-modernismo que, anos depois, seriam considerados por Jameson, Harvey, Eagleton e outros autores marxistas.
} 
social e uma nova ordem econômica" (JAMESON, 1998, p. 3), sem, com isso, aderir às ideologias da sociedade pós-industrial e congêneres.

Uma importante dimensão do argumento de Jameson, em sua apresentação do pós-modernismo como a "lógica cultural do capitalismo tardio", é a "simbiose" que teria ocorrido entre o cultural e o econômico. Dessa ótica, com o advento da indústria cultural e a subsequente perda da "autonomia relativa” que ela teria desfrutado um dia, longe da extinção da esfera cultural, o que ocorreu foi a sua "explosão":

[...] uma prodigiosa expansáo da cultura por todo o domínio do social, até o ponto em que tudo em nossa vida social - do valor econômico e do poder do Estado às práticas e à própria estrutura da psique - pode ser considerado como cultural, em um sentido original que não foi, até agora, teorizado. (JAMESON, 2007, p. 74).

Mesmo o bom funcionamento dos negócios exigiria, cada vez mais, a mobilização de mecanismos próprios à esfera cultural, bem como da aura de "criatividade", de "liberdade", e de "flexibilidade", de que se arvoram as produçóes estéticas (ARANTES, 2005, p.73).

No cerne desse processo, situar-se-ia a conversão da cultura em mercadoria "vedete", num mundo espetacular em que a imagem se sobrepóe e assume primazia em relação à própria coisa (DEBORD, 2000). "A imagem", afirma Jameson (1998, p. 135), "[...] é a mercadoria atual e é por isso que é inútil esperar dela uma negação da lógica da produção de mercadorias; é por isso, finalmente, que toda beleza hoje é meretriz". Assim, após a "explosão" do cultural, ao invés de sustentar uma tensão crítica ante a realidade formatada pelo rolo compressor capitalista, a um só tempo, e cinicamente, a busca pela fruição associada à beleza estética passa a mascarar e a afirmar tal realidade. Da mesma forma, teria perdido toda a sua potência crítica aquilo que outrora foi criado e mobilizado para chocar, para romper com as falsas harmonias e explicitar as contradiçốes do existente (JAMESON, 2002, p.158).

Se fôssemos buscar uma explicação que abarcasse também as mudanças na esfera da produção mencionadas, porém não analisadas por Jameson, notadamente a difusão dos serviços em detrimento da produção industrial stricto sensu, talvez fosse o caso de recorrer às análises de Marx. E isso tanto para pôr de lado o entulho ideológico que cerca o tema, e que embasou tantos decretos da obsolescência do marxismo e do surgimento da sociedade "pós-industrial", 
e mesmo "pós-capitalista", como para situarmos essas transformaçôes no interior de um corpus teórico abrangente, e ainda assim, rigoroso. Ao fazê-lo, lembraríamos de antemão que "[...] um serviço é nada mais que o efeito útil de um valor de uso, seja da mercadoria, seja do trabalho" (MARX, 1996, p. 310; MARX, 1978, p.76). Logo, serviço é toda atividade laboral cujo efeito útil não pode ser desvinculado da própria atividade, de modo que o seu resultado não se materializa em coisa independente da atividade. Nada tem a ver, por conseguinte, com o caráter produtivo ou improdutivo dessa atividade, e muito menos do ramo da produção no qual ela se situa, posto que o conceito de trabalho produtivo concerne à forma social (capital), e distingue o trabalho que participa da autovalorização do capital, daquele que é mobilizado por meio do dispêndio de renda (MARX, 1978, p.76). Aos tantos que confundem ambas as conceituaçôes, Marx direcionou uma crítica precisa:

[...] a mania de definir o trabalho produtivo e o improdutivo por seu conteúdo material origina-se [...] da concepçấo fetichista, peculiar ao modo de produção capitalista, e derivada de sua essência, que considera as determinaçóes formais econômicas, tais como ser mercadoria, ser trabalho produtivo, etc., como qualidade inerente em si mesma aos depositários materiais dessas determinaçôes formais ou categorias. (MARX, 1978, p.78).

Não obstante, Marx não deu maior atenção ao tema, já que em sua época os serviços constituíam "[...] magnitudes insignificantes se comparados com o volume da produção capitalista.” (MARX, 1978, p.76). Ocorre que, há décadas, esse quadro se alterou, tornando necessário considerar as peculiaridades desse amplo conjunto de atividades. Nesse sentido, afigura-se relevante o fato de o serviço não se materializar em "coisa", independente do trabalho que o produz. Ora, o caráter coisal é uma determinação essencial da mercadoria (MARX, 1996, p. 165) e do seu caráter fetichista (MARX, 1996, p.198); porém, parece que o capital foi capaz de suprir essa "carência" ("coisal”) com uma espécie de "duplicação publicitária" da existência das mercadorias e serviços no plano imagético; a imagem efetivou - como simulacro - a existência coisal das "mercadorias-serviço" e, em certo sentido, se sobrepôs à mercadoria-coisa, dando origem ao fetichismo próprio ao espetáculo, tal qual teorizado por Debord $(2000)^{9}$.

\footnotetext{
${ }^{9}$ Segundo Prado (2005a, p. 92-93), “[...] a produçấo de massa é substituída mais e mais pela produção aparentemente personalizada, que apela aos gostos e desejos de indivíduos postos objetivamente como pessoas despersonalizadas, meramente contemplativas e manipuláveis. Por criação e recriaçáo geramse cada vez mais necessidades imaginárias de indivíduos cada vez mais narcisistas, de tal modo que as
} 
Essa revolução repercutiu decisivamente na subjetividade e na psique individual. Diferentemente de Lyotard, longe de ver uma tendência à multiplicação da libido e a liberação de suas potências, ao analisar a atual fase de desenvolvimento capitalista, Jameson aponta para uma degradação do $e u$, concomitante a uma diminuição do afeto. Enquanto o sujeito se fragiliza e empobrece, sua vida psíquica se torna uma "montanha russa", oscilando da euforia consumista à depressão niilística. Essa bipolaridade constitui um padrão psíquico na pós-modernidade, contribuindo para a perda dos cortes geracionais e da própria historicidade. Logo, se outrora a experiência subjetiva dominante era a da alienação, o não-reconhecimento do "sujeito" no mundo objetivo ao seu redor e na sua intervenção prática sobre ele, agora a patologia reinante seria a fragmentação psíquica esquizofrênica (JAMESON, 2007, p. 42). Na acepçáo empregada por Jameson, tomada de Lacan, a onipresença do tempo presente, separado por um abismo intransponível do fluxo histórico, impediria o estabelecimento de cadeias de significação, imprescindíveis para a produção de um senso unitário de realidade (JAMESON, 2007, p. 53; HARVEY, 1992, p. 57, 271).

Não é à toa que diversas vertentes artísticas pós-modernas, mormente no cinema, oscilam entre a melancolia oriunda da perda do sentido histórico - numa busca ilusória pela redenção de um presente vazio de significação no simulacro de um passado qualquer (JAMESON, 2007, p. 45) - e a cristalização do "ultraespacial", uma estetização do caráter totalizante da acumulação capitalista.

Do mesmo modo, não surpreende que, dentre os principais recursos e procedimentos do pós-modernismo, destaca-se, como marca recorrente, o pastiche, uma "paródia vazia" do passado; uma forma de "parasitismo sobre o velho", neutralizada no potencial crítico que pudesse vir a ter (JAMESON, 2007, p. 43-45). Em consonância com Jameson, Anderson (1999, p. 67-68) dirá que, "[...] apagando-se num perpétuo presente, os estilos e imagens rétro proliferaram como substitutos do temporal", conduzindo à "[...] perda de qualquer senso ativo de história, seja como esperança, seja como memória”. Já

próprias coisas se transfiguram em imagens e representaçôes de que as próprias coisas enquanto tais são apenas suportes. É assim que a produçấo capitalista em estágio avançado repóe o fetiche da mercadoria, fazendo com que o caráter social do trabalho deixe de se apresentar como naturalidade de coisas, para passar a figurar como artificialidade de um mundo de criaçôes 'intelectuais' e 'artísticas' da própria indústria cultural. Chega-se, assim, àquilo que Debord chamou de sociedade do espetáculo, que 'não é um conjunto de imagens, mas uma relação social entre pessoas, mediada por imagens' (DEBORD, 2000, p. 14). Agora, o fetiche passa a ser posto consciente e compulsivamente". 
o acento de Zizek (2005, p. 301) recai sobre a falta de significado histórico do presente, ou sobre a impossibilidade de historicizar o presente, situando-o no evolver histórico.

Em meio à degeneração do tempo, ao mesmo tempo em que viceja, segundo Harvey (1992, p. 64), uma "cultura de museu" e uma "indústria da herança”, que potencializaram a comercialização da história e da cultura, o espaço passa a determinar o imaginário (JAMESON, 2007, p. 43), num contexto em que as tecnologias da comunicação fazem com que imagens de todo o mundo circulem freneticamente pelos lares, dando a impressão de controle absoluto sobre o espaço "global" (ANDERSON, 1999, p. 104; HARVEY, 1992, p.63). Assim, o espaço tampouco se mantém incólume face à emergência da pós-modernidade (JAMESON, 2007, p.70).

Dessa maneira, de acordo com Harvey (1992, p. 294), o modernismo e o pós-modernismo podem ser compreendidos como certa condiçấo espaçotemporal, rebentos de uma revolução nos conceitos de tempo e espaço. Segundo o argumento do autor, a despeito de seu caráter evanescente, no modernismo a unificação histórica não está ausente, mas é capciosa; aparece na forma de um continuum abstrato e irrefreável, sob a égide do "progresso". Enquanto os apologistas louvavam uma totalidade fragmentária e antagônica, traduzindo a crescente submissão mundial às forças da valorização do valor num avanço geral da humanidade, para muitos artistas inconformistas reacionários ou revolucionários - tratava-se de romper com esse continuum ideológico e perverso de assalto, num átimo, jogando por terra as expectativas conciliadoras e as veleidades de harmonização; e isso apontando ou não para um rearranjo social sob outras bases (num retorno a uma mítica comunidade desfeita, primitiva ou aristocrática, ou na construção de uma formação social sem clivagens de classe). Nesse sentido, Harvey (1992, p. 256) propóe que “[...] a oposição entre o Ser e o Vir-a-Ser é central na história do modernismo. É preciso vê-la em termos políticos como uma tensão entre o sentido do tempo e o foco do espaço", levando a resultados permanentemente mutáveis, imersos no torvelinho da acumulação.

São igualmente dignas de nota, ainda no que tange à subjetividade "pósmoderna”, algumas teses inspiradas pelas análises de Lacan (1975), segundo as quais, grosso modo, o imperativo do superego havia se tornado o "Goza!", a obrigação do gozo, em substituição à repressão ao gozo que vigorava "nos 
tempos de Freud ${ }^{10}$. Tal imperativo abstrato e irrealizável, posto que o gozo necessariamente dimana de uma experiência específica, a qual trai a "pureza" e a "desmesura" exigidas por esse superego contemporâneo (SAFATLE, 2005, p. 131), coaduna-se e impele ao consumismo predatório e sem peias. Os indivíduos são, portanto, premidos ao trabalho de Sísifo da satisfação de suas pulsões, sempre frustrados em seu intento.

Somos remetidos aqui ao conceito de dessublimação repressiva de Marcuse (1969), uma espécie de "resolução" socialmente administrada do conflito entre o princípio de realidade e o princípio do prazer; se a repressáo superegoica antes conduzia à sublimação dos impulsos sexuais sob diversas formas que, não obstante, sustentavam as tensóes entre ambos os princípios e, portanto, algum potencial crítico, a dessublimação emerge como uma forma de adequação ao princípio de realidade, sendo a "libertação" da sexualidade, ela mesmo tornada mercadoria, realizada sob a égide do capital. Assim, "[...] com a integração da esfera da sexualidade ao campo dos negócios e dos divertimentos, a própria repressão é recalcada" (MARCUSE, 1969, p.73, 1998, p.106). Não obstante a pertinência de tais proposiçóes, à luz das consideraçóes sobre o atual estatuto do superego, faz sentido o deslocamento proposto por Safatle, ao sugerir a vigência contemporânea de um sistema de "insatisfação administrada", no interior do qual as promessas de "prazer" e de "felicidade", associadas ao consumo, e a permanente mobilização para o gozo (consumista) necessária e sistematicamente redundam sempre em frustração (SAFATLE, 2005, p.132) ${ }^{11}$.

\footnotetext{
10 "Não estamos mais diante da velha situaçáo psicanalítica descrita por Freud por meio da ideia de supereu - situação que articulava civilização e repressão ao insistir que náo podemos gozar porque internalizamos proibiçóes sociais e uma autoridade paterna que culpabiliza o prazer sexual [...]. O que temos hoje é o exato oposto dessa situação. A injunção social diz hoje: 'Goze de todas as maneiras! Goze sua sexualidade, realize seu eu, encontre sua identidade sexual, alcance o sucesso ou, mesmo, goze uma ascese espiritual" (ZIZEK, 2003; KEHL, 2004, 2009; SAFATLE, 2005, p. 127-129).

${ }^{11}$ Segundo Adorno (2008, p. 105), as reiteradas incitaçóes ao divertimento e ao lazer, que pululavam da coluna de astrologia do Los Angeles Times, tornam-se paradoxais "[...] uma vez que necessidades instintuais contrárias à regra dos interesses racionais parecem ser comandadas por interesses racionais. Mesmo aquilo que é espontâneo e involuntário é transformando em uma parte da arbitrariedade e do controle. É como uma paródia do dito freudiano de que aquilo que é o id deveria tornar-se o ego: aquele é acionado, ou ordenado pela consciência. $\mathrm{O}$ sujeito é forçado a se divertir de modo a se ajustar ou, pelo menos, de modo a transmitir aos outros a imagem de alguém ajustado, pois apenas as pessoas ajustadas são aceitas como normais e podem ter sucesso. [...] Exigências instintuais são libertadas de seu aspecto ameaçador porque são tratadas como deveres a serem cumpridos: o conceito psicanalítico de Genußfähigkeit (capacidade para o prazer) já contém internamente essa conotação fatal. Ao mesmo tempo, entretanto, estende-se a censura".
} 
Assim, é evidente que não se está diante de uma situação em que caíram as normas, e em que a existência se tornou um "exercício de liberdade". Se, outrora, era preciso abrir mão de seus impulsos e "fazer o que um homem deve fazer", hoje em dia, por bem ou mediante crescentes e cotidianas doses de antidepressivos, neurolípticos, ansiolíticos etc., cada um deve se sentir feliz e confortável - mas nunca saciado - com seus grilhôes. Nas palavras de Zizek (2003, p. 7), em "nossa sociedade reflexiva", "[...] o poder totalitário avança ainda mais longe do que o poder autoritário tradicional", e o "dever" subsume o "prazer". Evidentemente, os efeitos psicopatológicos desse estado de coisas se fazem sentir de maneira náo menos radical; se, segundo Maria Rita Kehl, a perversão é atualmente o modo dominante de organização do laço social, Safatle (2005, p. 133-134) argumenta que a ansiedade, a depressão e o cinismo se tornaram os sintomas dominantes da contemporaneidade.

Diante de tấo decisivos desdobramentos objetivos e subjetivos, surge a questão: sob que condições históricas se forjou a emergência da pósmodernidade?

Para Jameson, haveria dois marcos do advento da pós-modernidade, a saber, a referida subsunção do inconsciente em decorrência da "[...] ascensão das mídias e da indústria da propaganda” (JAMESON, 2007, p. 61) e a plena submissáo da natureza, relacionada ao avanço capitalista por sobre as formas de produção agrícola arcaicas que subsistiriam na periferia do sistema antes da "Revolução Verde". Ao virtual desaparecimento de qualquer formação social pré-capitalista e de qualquer domínio natural preservado da ação humana (a extinção da "primeira natureza") corresponderia a expansão do domínio da cultura como uma "segunda natureza" e sua imbricação com a economia.

Paradoxalmente, dessa ótica, se as condições de emergência do pósmodernismo estiveram ligadas à consumação da modernização capitalista, o modernismo, por seu turno, teria tirado seu impulso vital da incompletude desse processo. Assim como o realismo, que dependeria de certa fé na estabilidade social e no progresso da razão, a qual teria sido devastada pelo próprio desenvolvimento capitalista, o modernismo seria fruto da "dialética da reificaçáo, que se apodera das propriedades e das subjetividades, das instituiçóes e das formas de um mundo pré-capitalista anterior, a fim de destituí-las de seu conteúdo hierático ou religioso" (JAMESON, 2002, p. 157), em meio a um processo caracterizado pela diferenciação interna e pela autonomização ante a totalidade social. As forças criativas, a afirmação da novidade, a veia revolucionária, que caracterizaram uma gama de realizaçóes modernistas, 
teriam como substrato o conflito entre o devir moderno e o tradicional, e a diacronia característica do desenvolvimento capitalista (JAMESON, 2007, p. 314-315). O pós-modernismo, ao contrário, adviria da afirmação plena desse modo de produção (JAMESON, 2007, p. 13), em meados do século XX. Mais precisamente, conforme a periodização feita por Jameson, o pósmodernismo corresponderia a um "novo momento do capitalismo", o qual “[...] pode ser datado do boom do pós-guerra nos Estados Unidos no final da década de 1940 e início da década de 1950 ou, na França, do estabelecimento da Quinta República em 1958. A década de 1960 é em muitos aspectos o

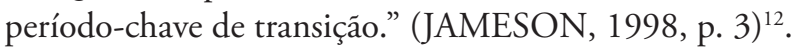

Procurando desenvolver as teses de Jameson, Perry Anderson propugna que o modernismo se originou da combinação de três fatores: uma formação social ainda em tensão com aquela que lhe precedeu, e em processo de consolidação sob bases predominantemente agrárias; o advento de radicais inovações tecnológicas, mas ainda pouco difundidas; e a possibilidade palpável de amplos levantes revolucionários. A Primeira Guerra Mundial teria representado um abalo desse quadro, com a destruição da velha ordem na Rússia, na Alemanha e na ÁustriaHungria, e com a debilitação geral da aristocracia fundiária. Não obstante, a difusão global da moderna organização industrial e do consumo de massa ainda estava por ocorrer, de tal modo que o combustível do modernismo continuava abundante. A situação apenas se alteraria com a Segunda Guerra Mundial, a qual teria enterrado definitivamente as elites agrárias, espalhando por todo o mundo não-soviético os padróes de consumo outrora exclusivos dos Estados Unidos e das democracias liberais, e afastando o espectro da revolução mundial. Apesar da sobrevida do modernismo nas duas ou três décadas que sucederam o fim do conflito mundial, nesse período sua energia vital evanesceu (ANDERSON, 1999, p. 97). Dessa forma, enquanto o modernismo adveio do assíncrono, da interação criativa entre tecnologia e arte, da perspectiva da transformação radical nas formas de sociabilidade, o pós-modernismo "[...] surgiu da combinação de uma ordem dominante desclassificada, uma tecnologia midiatizada e uma política sem nuances." (ANDERSON, 1999, p. 108).

Apesar de evocar brevemente outros fatores, Eagleton (1998) relaciona o advento do pós-modernismo à configuração assumida pelo conflito de classes no capitalismo contemporâneo; no entanto, ao invés do desaparecimento da

\footnotetext{
${ }^{12}$ Essa delimitação, um tanto imprecisa, corresponde em grande medida àquela feita por Mandel, em $O$ Capitalismo Tardio, obra determinante para a trajetória e a produção intelectual de Jameson, como ele próprio não cansa de reconhecer (JAMESON, 2007, p.397). Dessa forma, Jameson acaba reproduzindo as dificuldades de periodização do próprio Mandel (SINGER, 1982, p. XIX).
} 
classe burguesa (ANDERSON, 1999, p.102), ele enfatiza a derrota da classe operária ${ }^{13}$, no bojo das sublevaçóes de finais da década de 1960 (HARVEY, 1992, p. 44, 49).

\section{4 À GUISA DE CONCLUSÁO: PÓS-MODERNISMO E A HODIERNA DINÂMICA DA ACUMULAÇÃO DE CAPITAL}

Se várias dessas proposiçóes são pertinentes e indicam importantes dimensôes da atual fase da acumulação capitalista, a fundamentação historiográfica e a ancoragem do pós-modernismo a uma teoria abrangente sobretudo no que tange a uma apreensão conceitual rigorosa de sua evolução econômica, como cobra Anderson do "marxismo ocidental" - ainda se afiguram insuficientes. Remetendo a análises marxianas consagradas, Harvey (1992, p. 101) defende que o fundamento da "alteridade" louvada pelos pósmodernos e pelo atual senso comum continuaria sendo a contradição entre capital e trabalho, a forma social dominante e totalizadora e seu "outro" (sua substância e sua negação). Ademais, ele desenvolve uma analogia entre o dinheiro e as características essenciais do pós-modernismo, num contexto em que o dinheiro mundial havia perdido seu lastro material, e que objetos "artísticos" adquirem importância como reserva de valor (HARVEY, 1992, p. 268), sobretudo diante de abalos econômicos.

De fato, o nexo social estabelecido pela mediação do dinheiro (MARX, 1973, p.84) coaduna-se à fragmentação, ao culto à liberdade de troca, ao consumismo, ao fugaz, típicos do pós-modernismo, cuja "operação elementar" seria a de garantir o "acesso ao objeto", a virtualmente qualquer objeto, mas que antes tenha sido "privado de sua substância" (ZIZEK, 2005a, p.181). Igualmente, a afirmação pós-moderna da diferença e da alteridade expressa e oculta o fundamento da relação contraditória entre trabalho e capital, o qual se constitui em totalidade formal por meio de uma dupla redução: de si próprio à condição de capital constante, e a de seu outro, o trabalho vivo, à condição de capital variável, de modo a subsumir sua substância, a força de trabalho, fazendo-lhe oposição na forma de capital constante; e isso, ao mesmo tempo em que bloqueia a constituição do trabalho em totalidade, impedindo-o de se apropriar integralmente daquilo que produziu (GRESPAN, 2003).

13 "De onde mais que o pós-modernismo possa brotar [...] ele não deixa de ser, acima de tudo, o resultado de um fracasso político que ele ou jogou no esquecimento ou com o qual ficou o tempo todo brigando em pensamento" (EAGLETON, 1998, p.30). 
Também digno de menção é o paralelo que Harvey estabelece entre a afirmação da ficção em detrimento da função, principalmente por parte dos arquitetos pós-modernos, e o desenvolvimento dos mercados financeiros e suas fantasmagorias, nas últimas décadas (HARVEY, 1992, p. 104). Salta à vista que o elogio à dispersão, à fragmentação, ao efêmero, bem como a perda de referência no fluxo histórico, suprimido pela aceleração do tempo histórico e por sua "presentificação" absoluta (esquizofrênica), são fatores que alimentam a montanha russa do jogo bursátil e dos demais mercados financeiros, articulando-se à multiplicação de crises financeiras e econômicas, as quais reiteradamente resultam na reposição intensificada das condiçôes e da dinâmica econômica e social que as engendraram.

Ademais, salienta o autor, contra a "rigidez" que atingia os contratos de trabalho, as formas predominantes de investimento em capital fixo, o tipo de organização industrial e de planejamento produtivo dominante nos setores fordistas, as políticas governamentais assistenciais e previdenciárias, que consumiam montantes cada vez maiores de recursos, entre outros, mobilizou-se um vertiginoso desenvolvimento tecnológico e organizacional; o descentramento da produção e sua reestruturação em escala global (HARVEY, 1992, p. 267), tendo como marca distintiva o estabelecimento de amplos e complexos sistemas de terceirização (HARVEY, 1992, p. 150); a redução do tempo de rotação do capital; a destruição dos direitos trabalhistas; as inovaçôes financeiras; a produção "personalizada" (de escopo) e planejada para o aproveitamento das "externalidades de rede" (HARVEY, 1992, p. 140). Com isso, Harvey dá ênfase a relevantes transformações no âmbito da produção capitalista, as quais também comporiam o solo sobre o qual se firmou o pós-modernismo.

Recapitulando, foi visto como determinaçóes próprias à produção estética sob a indústria cultural - o pretenso caráter único e exclusivo dos chamados "bens culturais", a subsunção espetacular da coisa pela imagem, nas mais diversas dimensôes da existência, e a exigência narcisista de uma produção "personificada", uma singularidade simulada de supostos "sujeitos" cada vez mais pobres em determinaçóes - ligadas à busca por economias de escopo; esse conjunto de determinaçóes, dizíamos, passou a "recobrir" boa parte da produção e da distribuição. Ademais, somando-se à cultura pósmoderna do "gozo", aos mecanismos de "dessublimação repressiva" ou de "insatisfação administrada", associados à venalidade generalizada, afirmada de maneira tão entusiástica pelos pós-modernos, tais determinaçóes estão na base do consumismo desenfreado e da produçáo de uma demanda efetiva 
sustentada por um endividamento (público e privado) crônico, mais uma característica distintiva da hodierna dinâmica da acumulação de capital.

Por outro lado, destacou-se não apenas a relevância política e ideológica dos ramos produtivos mais diretamente relacionados ao pós-modernismo, próprios à indústria cultural e ao setor de comunicação, mas também sua importância propriamente econômica e sua posição de destaque no processo de retomada do crescimento do mercado mundial no pós-Segunda Guerra, bem como na consequente dispersão geográfica da produção e em sua integração (hierárquica) em escala global, como se revelou com a quebra da Nasdaq, em 2001 (BRENNER, 2003, p. 315).

Outra importante coordenada aqui, como se viu, consiste na ofensiva contra a classe trabalhadora e as perspectivas políticas anticapitalistas. Um traço decisivo da dinâmica social sob os "anos dourados do capitalismo" foi a burocratização e a integração sistêmica das organizaçóes operárias. Diante do fim da "ameaça vermelha" e num contexto de queda nas taxas de lucro, as elites lançaram-se numa luta ferrenha contra as organizaçôes trabalhistas, engajaramse em sucatear as dispendiosas estruturas de bem-estar social e, sobretudo, em aumentar o exército industrial de reserva - jogando por terra boa parte do poder de barganha dos sindicatos - assim como os lucros, em detrimento dos salários (MELLO, 2012, parte I). A ideologia pós-modernista favoreceu e legitimou a "contrarrevoluçáo neoliberal" e o credo do there is no alternative ${ }^{14}$.

Enfim, juntando os elementos expostos, é possível observar que o "pósmodernismo", em sua acepção marxista, concerne a processos sociais que não apenas exprimem a reconfiguração da dinâmica global de acumulaçáo de capital, a qual acabou por conformar uma nova fase de desenvolvimento desse modo de produção, mas que compreende uma dimensão fundante dele. Pelos múltiplos caminhos apenas indicados aqui, a crítica ao pós-modernismo amplia a compreensão da nossa época e torna profícuo o esforço de retomada dos debates que se travaram em torno dessa polissêmica noção, revelando sua atualidade.

\footnotetext{
${ }^{14}$ Caberia considerar ainda as articulaçôes entre a "estética da sordidez e do choque" pós-modernista, bem como suas determinaçôes fetichistas, e o avanço no velho esforço capitalista de estetização da política e da guerra (BENJAMIN, 1996, p. 196), de modo a apreender a consonância entre o pós-modernismo e o militarismo característico da atual fase do desenvolvimento capitalista (HARVEY, 2004).
} 
MELLO, Gustavo Moura de Cavalcanti. Post-modernism: between critique and ideology. Trans/form/ação, Marília, v. 39, n. 1, p. 233-258, Jan./Mar., 2016.

\begin{abstract}
The object of this article is the notion of postmodernism, a topic around which was established a wide-ranging debate that achieved wide publicity in the fairly recent past. This debate, however, has since cooled abruptly. We will seek to demonstrate that a critical consideration of this debate enhances our understanding of contemporary capitalism. We first make an effort at conceptual apprehension, in order to establish the main determinations (and indeterminations) of postmodernism. We then try to historically anchor the debate on postmodernism, locating certain connections between its theoretical development and underlying historical processes.
\end{abstract}

KEYWORDS: postmodernity, postmodernism, ideology, Marxism, contemporary capitalism.

\title{
REFERÊNCIAS
}

ADORNO, T. W. As estrelas descem à Terra. São Paulo: Editora UNESP, 2008. 194p.

; HORKHEIMER, M. A Dialética do esclarecimento: fragmentos filosóficos. Rio de Janeiro: Jorge Zahar, 1985. 254p.

ANDERSON, P. As Origens da pós-modernidade. Rio de Janeiro: Jorge Zahar, 1999. 188p.

ARANTES, O.B.F. A sobrevida da arquitetura moderna segundo Jürgen Habermas. In: _. Urbanismo em fim de linha e outros estudos sobre o colapso da modernização arquitetônica. São Paulo: EDUSP, 2001. p. 47-70.

. A "virada cultural" do sistema das artes. Margem Esquerda, n.6, p. 62-75, set. 2005.

BENJAMIN, W. A obra de arte na era de sua reprodutibilidade técnica. In: Magia e técnica, arte e política: ensaios sobre literatura e história da cultura. São Paulo: Brasiliense, 1996. p. 165-196.

BRENNER, R. O Boom e a bolha: os Estados Unidos na economia mundial. Rio de Janeiro: Record, 2003.

DEBORD, G. A Sociedade do espetáculo. Rio de Janeiro: Contraponto, 2000. 237p.

EAGLETON, T. Awakening from modernity. Times Literary Suplement, 20 de fevereiro de 1987.

. As ilusões do pós-modernismo. Rio de Janeiro: Zahar, 1998. 141p.

FAUSTO, R. Marx: lógica e política: investigaçôes para uma reconstituição do sentido da dialética. Tomo II. São Paulo: Brasiliense, 1987. 267p.

GRESPAN, J. L. A dialética do avesso. In: . Marxismo e ciências humanas. Sáo

Paulo: Xamá; CEMARX; IFCH, 2003. p. 26-44. 
HABERMAS, J. Técnica e ciência como ideologia. Lisboa: Edições 70, 1968. 149p.

Modernity: an incomplete project. New German, Critique, n. 22, p.3-15, 1981. Disponível em: <http://www.aphotostudent.com/wp-content/uploads/2009/11/ habermas_modernityproject.pdf>. Acesso em: 10 abr. 2012. set. 1987.

Arquitetura moderna e pós-moderna. Novos Estudos CEBRAP, n. 18, p.115-124,

. Teoría de la acción comunicativa. V. I. Madrid: Taurus, 1987a. 471p.

. Teoría de la acción comunicativa. V. II. Madrid: Taurus, 1987b. 485p.

. Que significa socialismo hoje? Revolução recuperadora e necessidade de revisão de esquerda. Novos Estudos CEBRAP, n. 30, p.43-61, jul. 1991.

. O Discurso filosófico da modernidade. São Paulo: Martins Fontes, 2000. 540p.

HARVEY, D. A condição pós-moderna. São Paulo: Loyola, 1992. 352p.

HORKHEIMER, M. O eclipse da razão. São Paulo: Centauro, 2002. 192p.

JAMESON, F. Postmodernism and consumer society. In: . The cultural turn: selected writings on the postmodern, 1983-1998. Londres: Verso, 1998. p. 1-20.

. Cultura e capital financeiro. In: A cultura do dinheiro: ensaios sobre a globalização. Petrópolis: Vozes, 2002b. p. 217-54.

Notas sobre a globalização como questão filosófica. In: A cultura do dinheiro: ensaios sobre a globalização. Petrópolis: Vozes, 2002a. p. 43-72.

$431 \mathrm{p}$.

. Pós-modernismo: a lógica cultural do capitalismo tardio. São Paulo: Ática, 2007.

KEHL, M.R. Fascismo banal. Revista Fórum, 2009. Disponível em: <http://www. revistaforum.net.br/conteudo/detalhe_noticia.php?codNoticia=7751>. Acesso em: $05 \mathrm{fev}$. 2012.

. Fetichismo. In: BUCCI, E.; KEHL, M. R. Videologias: ensaios sobre a televisão. São Paulo: Boitempo, 2004. 245p.

LACAN, J. Séminaire XX. Paris: Seuil, 1975. 186p.

LÖWY, M. Habermas e Weber. In: BENSAID, D.; LÖWY, M. Marxismo, modernidade, utopia. São Paulo: Xamã, 2000. 272p.

LYOTARD, J-F. A condição pós-moderna. Rio de Janeiro: José Olympio, 2004. 135p. . Moralidades pós-modernas. Campinas: Papirus, 1996. 222p.

MARCUSE, H. A ideologia da sociedade industrial: o homem unidimensional. Rio de Janeiro: Zahar, 1969. 238p.

. Cultura e sociedade II. São Paulo: Paz e Terra, 1998. 175p. 
MARX, K. Elementos Fundamentales para la Critica de la Economia Politica (borrador). V. I. Argentina: Siglo Veintiuno, 1973. 500p.

. Contribuição à crítica da Economia Política. Sáo Paulo: Martins Fontes, 1977. $351 \mathrm{p}$.

. O Capital: crítica da economia política. São Paulo: Nova Cultural: Livro I, Tomo I, 1996. (Os Economistas). 496p.

. O Capital: crítica da economia política. Livro II. São Paulo: Victor Civita, 1984. (Os Economistas). 365p.

. Capitulo sexto inédito de O Capital: resultados do processo de produção imediata. Porto: Escorpião, 1978. 170p.

MELLO, G. M. C. Teorias Marxistas sobre o capitalismo contemporâneo.2012. $324 \mathrm{f}$. Tese (Doutorado em Sociologia). Faculdade de Filosofia, Letras e Ciências Humanas da Universidade de São Paulo, São Paulo, 2012.

PRADO, E.F.S. Pacificação do conflito de classes? In: Desmedida do valor. São Paulo: Xamá, 2005. p. 19-48.

. Crítica à economia política do imaterial. In: Desmedida do valor: crítica da pós-grande indústria. São Paulo: Xamã, 2005. p. 71-94.

SAFATLE, V. Depois da culpabilidade: figuras do supereu na sociedade de consumo. In: DUNKER, C.; PRADO, J.L. (Org.). Zizek Crítico. São Paulo: Hacker, 2005. p. 119-140.

SCHWARZ, R. Fim de Século. In: . Sequências brasileiras. São Paulo: Companhia das Letras, 1999. p. 155-162.

. O pai de família e outros estudos. São Paulo: Companhia das Letras, 2008. 148p.

SINGER, P. Apresentação. In: MANDEL, E. O capitalismo tardio. São Paulo: Abril Cultural, 1982. p. VII-XXXIII.

VENTURI, R.; BROWN, D.S.; IZENOUR, S. Learning from Las Vegas: the forgotten symbolism of architectural form. Cambridge: MIT Press, 1995. 192p.

ZIZEK, S. Multiculturalismo ou a lógica cultural do capitalismo multinacional. In: DUNKER, C.; PRADO, J.L. (Org.). Zizek Crítico. São Paulo: Hacker, 2005. p. 11-45.

. Posfácio: a escolha de Lênin. In: . (Org.). Às portas da Revolução: escritos de Lênin de 1917. São Paulo: Boitempo, 2005a. p. 171-342.

. "O superego pós-moderno". Folha de S. Paulo, 23 maio 2003. Disponível em: <http://pt.scribd.com/doc/19133295/Zizek-O-superego-posmoderno>. Acesso em: 02 fev. 2012.

Recebido em 01/12/2015

Aceito em 08/01/2016 